\title{
Estimating mercury emission outflow from East Asia using CMAQ-Hg
}

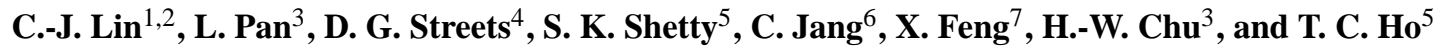 \\ ${ }^{1}$ Department of Civil Engineering, Lamar University, Beaumont, TX 77710, USA \\ ${ }^{2}$ School of Environmental Science \& Engineering, South China University of Technology, Guangzhou, 510006, \\ Guangdong, China \\ ${ }^{3}$ Department of Mechanical Engineering, Lamar University, Beaumont, TX 77710, USA \\ ${ }^{4}$ Decision and Information Sciences Division, Argonne National Laboratory, Argonne, IL 60439, USA \\ ${ }^{5}$ Department of Chemical Engineering, Lamar University, Beaumont, TX 77710, USA \\ ${ }^{6}$ Office of Air Quality Planning and Standards, USEPA, Research Triangle Park, NC 27711, USA \\ ${ }^{7}$ State Key Laboratory of Environmental Geochemistry, Institute of Geochemistry, Chinese Academy of Sciences, \\ Guiyang 550002, China
}

Received: 19 September 2009 - Published in Atmos. Chem. Phys. Discuss.: 9 October 2009

Revised: 2 February 2010 - Accepted: 3 February 2010 - Published: 17 February 2010

\begin{abstract}
East Asia contributes to nearly 50\% of the global anthropogenic mercury emissions into the atmosphere. Recently, there have been concerns about the long-range transport of mercury from East Asia, which may lead to enhanced dry and wet depositions in other regions. In this study, we performed four monthly simulations (January, April, July and October in 2005) using CMAQ-Hg v4.6 for a number of emission inventory scenarios in an East Asian model domain. Coupled with mass balance analyses, the chemical transport of mercury in East Asia and the resulted mercury emission outflow were investigated. The total annual mercury deposition in the region was estimated to be $821 \mathrm{Mg}$, with $396 \mathrm{Mg}$ contributed by wet deposition and $425 \mathrm{Mg}$ by dry deposition. Anthropogenic emissions were responsible for most of the estimated deposition (75\%). The deposition caused by emissions from natural sources was less important $(25 \%)$. Regional mercury transport budgets showed strong seasonal variability, with a net removal of RGM (7$15 \mathrm{Mg}$ month $^{-1}$ ) and PHg (13-21 Mg month ${ }^{-1}$ ) in the domain, and a net export of GEM (60-130 Mg month $\left.{ }^{-1}\right)$ from the domain. The outflow caused by East Asian emissions (anthropogenic plus natural) was estimated to be in the range of $1369-1671 \mathrm{Mg} \mathrm{yr}^{-1}$, of which $50-60 \%$ was caused by emissions from natural sources. The emission outflow rep-
\end{abstract}

\section{Correspondence to: C.-J. Lin}

(jerry.lin@lamar.edu) resented about $75 \%$ of the total mercury emissions in the region, and would contribute to $20-30 \%$ of mercury deposition in remote receptors.

\section{Introduction}

Mercury is a global pollutant subject to long-range transport due to the long atmospheric lifetime of gaseous elemental mercury (GEM, 0.5-2 years) (Selin et al., 2007; Schroeder and Munthe, 1998; Lin and Pehkonen, 1999; Shia et al., 1999; Lindberg et al., 2007). On the other hand, oxidized mercury [likely $\mathrm{Hg}(\mathrm{II})$ ], either in the form of reactive gaseous mercury (RGM) or particulate mercury $(\mathrm{PHg})$, can be quickly removed from the atmosphere via wet and dry deposition (Lindberg et al., 2002; Schroeder et al., 1998; Lin and Pehkonen, 1999; Stratton et al., 2001). Once deposited, its methylation and bioaccumulation in the food chain pose a threat to human health, particularly for the sensitive subpopulations (Rolfhus et al., 2003; Mason et al., 1995, 2006; Miller et al., 2007).

East Asia is the largest mercury source region in the world. It contributes to about $50 \%$ of all anthropogenic emissions to the atmosphere (Pacyna et al., 2006; Streets et al., 2009). Recently, there were a number of studies reporting experimental and modeling evidences of long-range transport of atmospheric mercury. For example, observational analyses

Published by Copernicus Publications on behalf of the European Geosciences Union. 
using $\mathrm{Hg}^{\circ}$ to $\mathrm{CO}$ concentration ratio have shown that mercury plumes from East Asia can travel across the Pacific to the west coast of North America (Jaffe et al., 2005; WeissPenzias et al., 2007; Weiss-Penzias et al., 2006). Global model simulations estimated that the long-range transport could contribute to $5-36 \%$ of the total deposition in North America depending on the locations (Jaffe and Strode, 2008; Seigneur et al., 2004). However, the impact of regional emission uncertainties (Wu et al., 2006; Shetty et al., 2008; Streets et al., 2005) on the source-receptor attribution has not been addressed. In addition, the chemical transport budgets of atmospheric mercury in the region have not been investigated extensively.

To understand the impact of mercury emissions in East Asia on mercury concentration and deposition in other regions, a better understanding of the transport, transformation and deposition in the region is needed. Although preliminary measurement and modeling analyses suggested that mercury emission outflow from the region may be significant (Pan et al., 2006, 2008; Friedli et al., 2004; Weiss-Penzias et al., 2007), there were few studies that provided detailed quantitative assessments. One approach to study regional emission outflow of air pollutants is to construct the mass budget of the pollutant of interest (Lamborg et al., 1995; Moussiopoulos et al., 2004). Coupled with a comprehensive modeling assessment, the sources, sinks and associated chemical transport pathways can be understood quantitatively.

In this study, the mercury model of the USEPA Community Multi-scale Air Quality modeling system (CMAQ-Hg) (Bullock and Brehme, 2002; Byun and Schere, 2006) was applied to simulate the emissions, transport, and deposition of atmospheric mercury in a model domain covering the East Asian region. The model results were analyzed to estimate the seasonal and annual mercury outflow caused by the emissions in the region. The outflow was estimated under three emission inventory (EI) scenarios to understand the impact of emission uncertainties. This work, to our knowledge, is the first modeling assessment on regional chemical transport of atmospheric mercury in the region, and a part of the modeling efforts of the USEPA's Intercontinental transport and Climatic effects of Air Pollutants (ICAP) Program to understand the effect of air emissions outside of the US to regional air quality via long-range transport.

\section{Methods}

\subsection{Model domain and input data}

\subsubsection{Model domain}

The ICAP East Asian domain is in Lambert conformal projection centered at $34^{\circ} \mathrm{N}$ and $110^{\circ} \mathrm{E}$. The domain contains $97 \times 164$ horizontal grid cells at a spatial resolution of $36 \mathrm{~km}$. It covers China and other parts of Asia, including Bhutan,
Myanmar, northeastern India, Bangladesh, Nepal, northern Laos, Vietnam, Japan, Taiwan, North Korea, South Korea, and southern Mongolia (Fig. 1). The domain has 14 vertical layers.

\subsubsection{Meteorological data and modeling periods}

Hourly meteorological fields were used for model simulations. To study the seasonal trend of mercury chemical transport, the simulations were performed for four seasonal months (January, April, July and October) in 2005. The meteorological data were prepared by the ICAP program using a Meso-scale Meteorological Model (MM5 version 3.7) (Grell et al., 1994). The quality-assured MM5 outputs were processed to the CMAQ model-ready format using the Meteorology-Chemistry Interface Processor (MCIP version 3.3) as described by Byun and Ching (1999). In the MCIP processing, the dry deposition velocities ( $\left.V_{\mathrm{dep}}\right)$ of GEM and RGM were calculated using the M3DRY scheme (Pleim and Byun, 2004). The $V_{\text {dep }}$ of PHg was calculated similar to that of fine aerosols in Aitken and accumulation modes.

\subsubsection{Emission inventory}

Anthropogenic mercury EI in China was based on the work of Streets and coworkers (Streets et al., 2005; Wu et al., 2006) for Year 2001. The EI outside of China was based on the work by Pacyna and coworkers (Pacyna et al., 2006) for Year 2000. We recognized that the base years of the inventory data were not consistent with the modeling period. However, the EI data represented the most updated data at the time when the study was conducted. The emission speciation followed the recommendations of Streets et al. (2005), which provided specific speciation profiles for different emission source categories in China. On average, there were $56 \%$ of GEM, $32 \%$ of RGM, and $12 \%$ of PHg in the mercury EI. Emissions of GEM from natural sources were prepared following the approaches of Shetty et al. (2008).

To understand the impact of emission uncertainties on the outflow estimates, three EI scenarios were considered for the study domain (Table 1). The base case included mercury emissions from both anthropogenic and natural sources as discussed earlier (denoted as "Base" case). Since the anthropogenic emissions might be underestimated (Shetty et al., 2008; Friedli et al., 2004; Weiss-Penzias et al., 2007), an inferred, scaled-up emission dataset from inverse modeling results was also considered (Pan et al., 2007) (denoted as "Inferred" case). To understand the relative importance of different emission sources in the model results, a case considering emissions from natural sources only was also performed (denoted as "Natural Only" case). The spatial distribution of the gridded Base case EI is shown in Fig. 1. The greater emission quantity in July was due to the higher surface temperature and solar radiation that enhanced the emissions from 

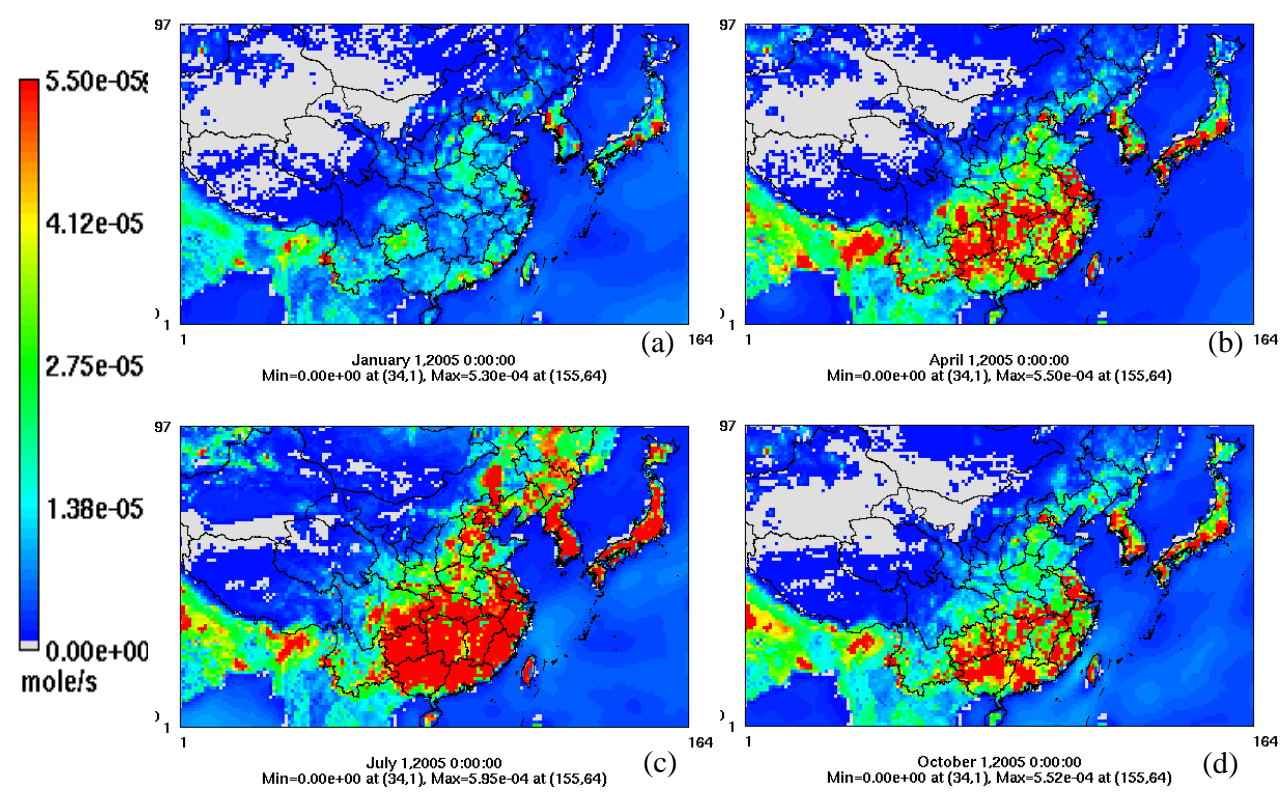

Fig. 1. Spatial distribution of the Base case mercury emissions (GEM+RGM+PHg) in the study domain in (a) January, (b) April, (c) July, and (d) October.

Table 1. Mercury emission scenarios considered in the study domain $\left(\mathrm{Mg} \mathrm{yr}^{-1}\right)$.

\begin{tabular}{lrrrrr}
\hline Scenarios & GEM & RGM & PHg & $\begin{array}{r}\text { Domain } \\
\text { Total }\end{array}$ & $\begin{array}{c}\text { Anthrop. } \\
\text { Emission }\end{array}$ \\
\hline Base Case $^{\mathrm{a}}$ & 1249 & 275 & 89 & 1793 & 826 \\
Inferred $^{\mathrm{b}}$ & 1669 & 434 & 155 & 2258 & 1390 \\
Natural Only $^{\mathrm{c}}$ & 968 & 0 & 0 & 968 & 0 \\
\hline
\end{tabular}

a Anthropogenic emissions from Wu et al. (2006) and Pacyna et al. (2006), plus emissions from natural sources.

$\mathrm{b}$ Anthrop. emission from the scaled-up values from inverse modeling (Pan et al., 2007), plus emissions from natural sources.

c Emissions from natural sources based on the methods by Shetty et al. (2008).

natural sources. The EI for other criteria pollutants was based on the emission data originally developed in a NASA's study on the Transport and Chemical Evolution over the Pacific (TRACE-P, Carmichael et al., 2003) with continuous updates for year 2005 .

\subsubsection{Boundary and initial conditions}

Boundary and initial conditions (BC/ICs) were re-gridded from the outputs of a global 3-D chemical transport model, GEOS-Chem CTM (Selin et al., 2007), into the map projection of the study domain. To understand the effect of $\mathrm{BCs}$ on the estimated outflow, simulations using "back- ground" BC/ICs were also performed (details see Sect. 2.3). The background BC/ICs assumed a GEM concentration of $1.2 \mathrm{ng} \mathrm{m}^{-3}$ and zero concentration of RGM and $\mathrm{PHg}$.

\subsection{Chemical transport models}

CMAQ-Hg version 4.6 was used for all simulations. The model components, science updates, and model uncertainty issues have been discussed in details earlier (Bullock and Brehme, 2002; Lin et al., 2006b, 2007; Pongprueksa et al., 2008). The Carbon Bond mechanism (CB05) was used as the gas-phase chemical mechanism to generate the concentrations of photochemical oxidants. The Rosenbrock solver (ROS3 in CMAQ CTM) was used as the chemical solver because of its flexibility (not mechanism specific). A global mass-conserving scheme (YAMO) was used for vertical and horizontal advection calculation, and the K-theory eddy diffusivity scheme was used for vertical diffusion (documentation for these schemes is available at http://www.cmascenter. org).

\subsection{Calculation of regional mercury mass budgets}

Mercury emission outflow from the domain was estimated by calculating the chemical transport budget of mercury mass using CMAQ-Hg simulation results for each modeling month. A schematic for the mass budget calculation is shown in Fig. 2. The change of mercury mass within the domain over a simulation period can be influenced by the mercury mass entering and leaving the domain through atmospheric transport, the emissions from anthropogenic and 


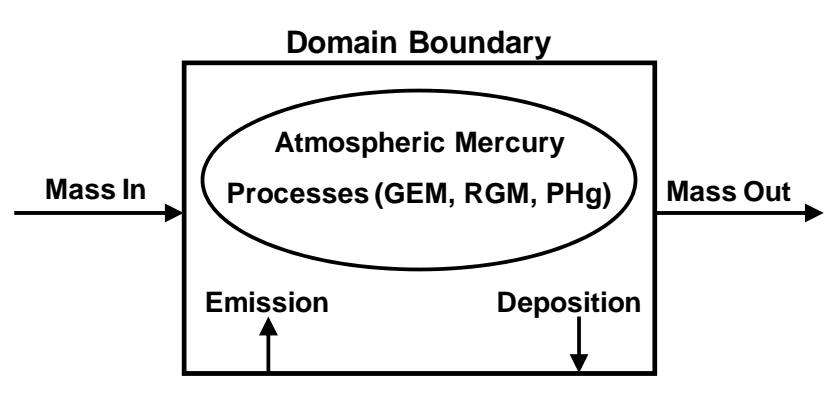

Fig. 2. Schematics of the method used for calculating regional mercury mass budgets.

natural sources, and the deposition controlled by the chemical and physical processes in the atmosphere (e.g., chemistry, scavenging, mixing, etc.). The net change of mercury mass within the domain is the difference between mercury masses at the beginning and at the end of the modeling period:

$C M=F M-I M=I-O+E-D$

Where $C M$ is the net change of mercury mass, $F M$ is the air mercury mass in the domain at the end of the modeling period (final mass), and $I M$ is the air mercury mass in the domain at the beginning of the modeling period (initial mass). $I$ is the air mercury mass that enters the domain, $O$ is the air mercury mass that leaves the domain, $E$ is the emission input to the air in the domain, and $D$ is the deposition removal of mercury mass from the air in the domain over the modeling period. All the terms are in $\mathrm{Mg}$. Since $I$ and $O$ represent the mercury mass associated with the atmospheric transport into and out of the study domain, the transport budget $(T B)$ can be defined as:

$T B=O-I=E-D-F M+I M$

The transport mass budgets for GEM, RGM and PHg were calculated for each of the modeling months. A positive value of transport budget indicates a net export of mercury mass in air leaving the domain (what's going out is greater than what's coming in); while a negative value indicates a net removal of mercury mass from air coming into the domain. To validate that the mercury mass was conserved in the calculation of atmopsheric transport in CMAQ v4.6, a set of tracer simulations in the study domain was performed by assuming a fixed value of mercury concentration $\left(1.5 \mathrm{ng} \mathrm{m}^{-3}\right)$ as BC/ICs without invoking the calculations for chemistry and deposition. After one month of simulation, nearly no change of mercury concentration $(<0.1 \%)$ was observed throughout the domains.

The mercury outflow caused (or enhanced) by the mercury emissions within the domain $(O F)$ can be considered as the difference in transport budgets between when there is emission input and when there is no emission input, i.e.:

$O F=T B_{i}-T B_{o}$
Where $T B_{i}$ is the transport budget corresponding to one of the emission scenarios shown in Table 1 , and $T B_{o}$ is the transport budget under zero emission input. Equation (3) estimates the actual mercury emission outflow from the study domain, which is independent of the BC/ICs used in the simulations. To verify that the estimated mercury outflow is not influenced by $\mathrm{BC} / \mathrm{ICs}$, the outflow was estimated using two different sets of BC/ICs as described in Sect. 2.1.4. The estimated outflows $(O F)$ were found to be identical for both $\mathrm{BC} / \mathrm{IC}$ cases.

\subsection{Data analysis}

The CMAQ-Hg model outputs were in network common data format (netCDF). A suite of netCDF file operators developed by Zender and Mangalarn (2007) were used for the analysis of the model data. The Package for Analysis and Visualization of Environmental data (PAVE) version 2.3 (available at http://www.cmascenter.org) was used for data visualization.

\section{Results and discussion}

\subsection{Model-predicted mercury concentrations in East Asia and model verification}

The spatial distribution of monthly average surface concentration of total mercury $\left(\mathrm{ng} \mathrm{m}^{-3}\right)$ in East Asia is shown in Fig. 3 for each model month. The model results were generated using the Base case emissions (Table 1 and Fig. 1) and GEOS-Chem BC/ICs. There are two important features in Fig. 3. One is that the surface concentration resembled the spatial pattern of emissions from natural sources (Shetty et al., 2008) with a footprint of large point source emissions. Mercury emissions from large point sources accounted for about $45 \%$ of mercury anthropogenic emissions in China. The hotspots caused by these emissions, including the elevated concentrations in the provinces of Liaoning, Hebei, Guangdong, Guizhou, and Gansu, can be clearly seen in the month of January (Fig. 3a) when the emissions from natural sources was the weakest. Most of the large point source emissions were from coal combustion and the smelting processes of zinc and lead (Streets et al., 2005). In contrast to area and natural sources (which typically release mercury into the surface layer only), point source emissions have higher temperatures and are released at higher altitudes. Therefore, they have a greater potential to enter the free troposphere for long-range transport. The other feature is that there was a strong concentration gradient from the East Asian continent to the Pacific Ocean, suggesting that circumpolar westerlies transport the mercury emissions from the sources into the Pacific.

The model-predicted mercury concentrations in the study domain ranged from 1.1 to $9.3 \mathrm{ng} \mathrm{m}^{-3}$, with $85-99 \%$ of total mercury constituted by GEM. These results are consistent with earlier global model predictions (Seigneur et al., 

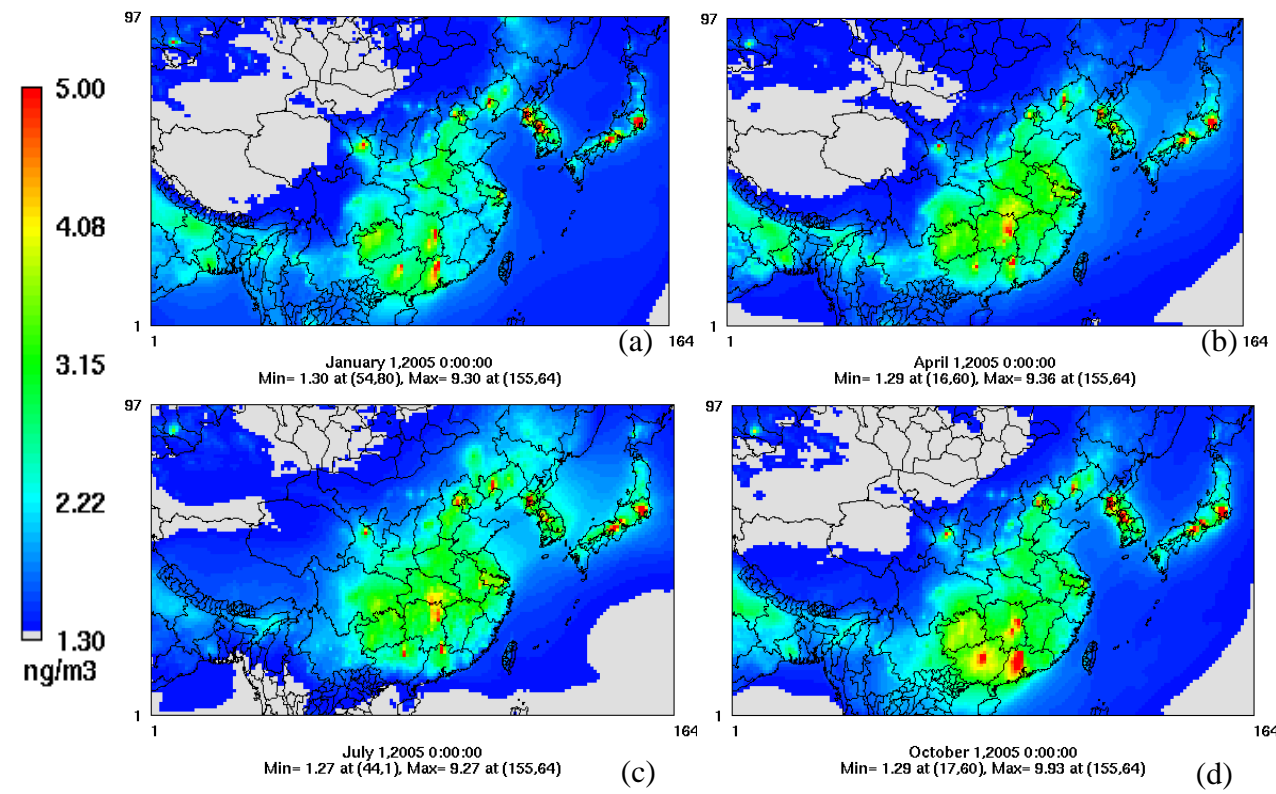

April 1,2005 0:00:00
$\operatorname{Min}=1.29$ at $(16,60), \operatorname{Max}=9.36$ at $(155,64)$

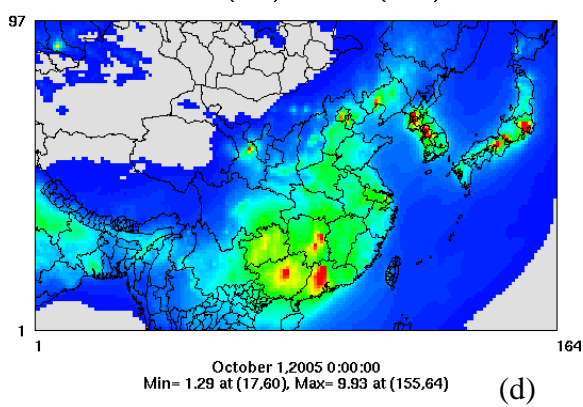

Fig. 3. Spatial distribution of the monthly average surface concentrations $\left(\mathrm{ng} \mathrm{m}^{-3}\right)$ of total mercury $(\mathrm{GEM}+\mathrm{RGM}+\mathrm{PHg}) \mathrm{using}$ the $\mathrm{Base}$ case emissions and GEOS-Chem BC/ICs in (a) January, (b) April, (c) July, and (d) October.

2004; Selin et al., 2007; Strode et al., 2008). The fraction of RGM and PHg was typically greater at locations near large point sources due to the emission speciation (nearly $50 \%$ of mercury was emitted as RGM and $\mathrm{PHg}$ ), and decreased rapidly away from source locations because of their relatively shorter atmospheric lifetime. The predicted surface concentrations were compared to the observed concentrations in the East Asian region (Liu et al., 2002; Wang et al.,, 2006 2007; Fang et al., 2001, 2004; Feng et al., 2004a; Yang et al., 2009; Xiu et al., 2009; Fu et al., 2008a, b; Wan et al., 2009a; Wan et al., 2009b; Kim et al., 2009; Nguyen et al., 2007; Chand et al., 2008). We recognized that the timeframe of measurements reported in the literature was not synchronized with the model and emission inventory base years in this study. However, because the air mercury concentration did not change significantly over the past few years (Choi et al., 2009; Kim et al., 2009; Wan et al., 2009a, b) in the region, model verification by comparing the model results to the measured mercury concentrations yielded valuable insights to model performance. The comparison is summarized in Table 2.

As seen in Table 2, the model-predicted concentrations are generally consistent with observations. The simulated GEM concentrations at remote sites agreed excellently with field observations. However, the model under-predicted GEM concentrations at most urban sites in China by missing the peak observed concentrations. This is because some of the urban sites were intended to capture urban emission plumes. Therefore, the model-predicted values were comparatively lower because of the focus of regional assessment in this study. The uncertainties of mercury emissions, which have been thought to be underestimated or miss certain emission sources (Pan et al., 2006; Weiss-Penzias et al., 2007; Friedli et al., 2004; Feng et al., 2004a, 2005), might also be important reasons for the under-prediction of GEM. Model predictions of RGM and PHg agreed reasonably well with the observations made in China, but over-predicted those observed in South Korea and at Cape Hedo, Japan (Table 2). Process analysis of model results for ozone and $\mathrm{OH}$ concentrations revealed that the photochemistry was simulated appropriately. The over-prediction of RGM and PHg could be due to the production of RGM in the marine boundary layer (Holmes et al., 2009), which was not considered in CMAQ$\mathrm{Hg}$. It might also be due to the uncertainty in the emission speciation, the low $V_{\text {dep }}$ of RGM/PHg predicted by model over water surfaces, and possibly the residual photochemical activities off the continent.

\subsection{Model-predicted mercury deposition in East Asia}

The spatial distributions of monthly cumulated dry and wet deposition of mercury (normalized to $\mu \mathrm{g} \mathrm{m}^{-2} \mathrm{yr}^{-1}$ in each grid cell) predicted by model using the Base case emissions and GEOS-Chem BC/ICs are shown in Figs. 4 and 5. The spatial distribution of dry deposition resembled the footprint of the source locations of anthropogenic emissions (Fig. 4). The greatest deposition occurred at the immediate proximity of the emission sources, mainly in the major urban areas of China, Korea, and Japan. The simulated dry deposition typically ranged from 10 to $150 \mu \mathrm{g} \mathrm{m}^{-2} \mathrm{yr}^{-1}$, with values exceeding $300 \mu \mathrm{g} \mathrm{m}^{-2} \mathrm{yr}^{-1}$ near large point sources. The month of April appeared to have a slightly larger deposition 
Table 2. Comparison of the base-case model results with the field observations in the East Asian region.

\begin{tabular}{|c|c|c|c|c|c|c|c|c|c|c|}
\hline \multirow[t]{2}{*}{ Station } & \multirow[t]{2}{*}{ Location } & \multirow[t]{2}{*}{ Category } & \multicolumn{3}{|c|}{ Observations } & \multirow{2}{*}{$\begin{array}{l}\text { Date/ } \\
\text { Period }\end{array}$} & \multicolumn{3}{|c|}{ Model Results } & \multirow[t]{2}{*}{ Ref.* } \\
\hline & & & $\operatorname{GEM}\left(\mathrm{ng} / \mathrm{m}^{3}\right)$ & $\operatorname{RGM}\left(\mathrm{pg} / \mathrm{m}^{3}\right)$ & $\mathrm{PHg}\left(\mathrm{pg} / \mathrm{m}^{3}\right)$ & & $\operatorname{GEM}\left(\mathrm{ng} / \mathrm{m}^{3}\right)$ & $\operatorname{RGM}\left(\mathrm{pg} / \mathrm{m}^{3}\right)$ & $\mathrm{PHg}\left(\mathrm{pg} / \mathrm{m}^{3}\right)$ & \\
\hline Waliguan, & $100.9^{\circ} \mathrm{E}$ & Remote & $1.7 \pm 1.1$ & & & Dec-05 & $1.46(1.16-3.18)$ & & & 1 \\
\hline China & $36.3^{\circ} \mathrm{N}$ & & $0.6 \pm 0.1$ & & & Aug-05 & & & & \\
\hline Yangzi River & $120.7^{\circ} \mathrm{E}$ & Suburban & $5.4 \pm 4.1$ & & & Sep-05 & $2.49(1.36-8.06)$ & & & 1 \\
\hline Delta, China & $30.8^{\circ} \mathrm{N}$ & & & & & & & & & \\
\hline Guangzhou, & $113.3^{\circ} \mathrm{E}$ & Urban & $13.5 \pm 7.1$ & & & Jan-05 & $3.15(1.46-9.93)$ & & & 1 \\
\hline China & $23.2^{\circ} \mathrm{N}$ & & & & & & & & & \\
\hline Beijing, & $116.4^{\circ} \mathrm{E}$ & Urban & $8.3 \pm 3.6$ & & $180-3510$ & Jan-05 & $2.38(1.35-4.80)$ & & $751(17.1-2357)$ & 1,2 \\
\hline China & $39.9^{\circ} \mathrm{N}$ & & $6.5 \pm 5.2$ & & & Apr-05 & $2.50(1.28-6.68)$ & & & \\
\hline & & & $4.9 \pm 3.3$ & & & Jul-05 & $3.36(1.76-7.75)$ & & & \\
\hline & & & $6.7 \pm 3.5$ & & & Oct-05 & $2.88(1.38-6.83)$ & & & \\
\hline Beijing,China & $\begin{array}{l}116.7^{\circ} \mathrm{E} \\
40.0^{\circ} \mathrm{N}\end{array}$ & Rural & $1.8-4.6$ & & & Feb-98 & $2.67(1.28-9.17)$ & & & 3 \\
\hline Changchun, & $125.3^{\circ} \mathrm{E}$ & Urban & $18.4(4.7-79.6)$ & & $22-1984$ & Jul-09- & $1.84(1.20-4.9)$ & & $258(0.02-695)$ & 4,5 \\
\hline China & $43.8^{\circ} \mathrm{N}$ & Suburban & $11.7(2.3-25.6)$ & & & Jul-00 & & & & \\
\hline $\begin{array}{l}\text { Guiyang, } \\
\text { China }\end{array}$ & $\begin{array}{l}106.7^{\circ} \mathrm{E} \\
26.6^{\circ} \mathrm{N}\end{array}$ & Urban & $8.4 \pm 4.9$ & & & $\begin{array}{l}\text { Nov-01- } \\
\text { Nov-02 }\end{array}$ & $2.83(1.20-5.65)$ & & & 6 \\
\hline $\begin{array}{l}\text { Chongqing, } \\
\text { China }\end{array}$ & $\begin{array}{l}106.5^{\circ} \mathrm{E} \\
29.5^{\circ} \mathrm{N}\end{array}$ & Urban & $6.74 \pm 0.37$ & & & $\begin{array}{l}\text { Aug-06- } \\
\text { Sep-07 }\end{array}$ & $2.81(1.37-5.22)$ & & & 7 \\
\hline $\begin{array}{l}\text { Shanghai, } \\
\text { China }\end{array}$ & $\begin{array}{l}121.4^{\circ} \mathrm{E} \\
31.1^{\circ} \mathrm{N}\end{array}$ & Urban & & & $70-1450$ & $\begin{array}{l}\text { Jul-04- } \\
\text { Apr-06 }\end{array}$ & & & $230(0.01-1960)$ & 8 \\
\hline $\begin{array}{l}\text { Mt. Gongga, } \\
\text { China }\end{array}$ & $\begin{array}{l}102.7^{\circ} \mathrm{E} \\
29.9^{\circ} \mathrm{N}\end{array}$ & Remote & $4.0(0.5-21.0)$ & 6.2 & 30.7 & $\begin{array}{l}\text { May-05- } \\
\text { Apr-06 }\end{array}$ & $2.20(1.20-8.28)$ & $31.4(0.03-116)$ & $75.8(0.03-482)$ & 9,10 \\
\hline $\begin{array}{l}\text { Changbaisan, } \\
\text { China }\end{array}$ & $\begin{array}{l}128.3^{\circ} \mathrm{E} \\
42.2^{\circ} \mathrm{N}\end{array}$ & Remote & $3.58 \pm 1.78$ & 65.0 & 77.0 & $\begin{array}{l}\text { Aug-05- } \\
\text { Jul-06 }\end{array}$ & $1.57(1.19-2.80)$ & $25.3(0.02-118)$ & $129(0.01-488)$ & 11,12 \\
\hline Seoul, Korea & $\begin{array}{l}127.0^{\circ} \mathrm{E} \\
37.5^{\circ} \mathrm{N}\end{array}$ & Urban & $3.22 \pm 2.1$ & $27.2 \pm 19.3$ & $23.9 \pm 19.6$ & $\begin{array}{l}\text { Feb-05- } \\
\text { Feb-06 }\end{array}$ & $3.68(1.36-8.17)$ & $532(0.01-1766)$ & $403(0.03-1641)$ & 13 \\
\hline $\begin{array}{l}\text { An-Myum } \\
\text { Island, Korea }\end{array}$ & $\begin{array}{l}126.3^{\circ} \mathrm{E} \\
36.5^{\circ} \mathrm{N}\end{array}$ & Rural & $4.6 \pm 2.2$ & & & $\begin{array}{l}\text { Dec-04- } \\
\text { Apr-06 }\end{array}$ & $1.60(1.20-5.54)$ & & & 14 \\
\hline $\begin{array}{l}\text { Cape Hedo, } \\
\text { Japan }\end{array}$ & $\begin{array}{l}128.2^{\circ} \mathrm{E} \\
26.8^{\circ} \mathrm{N}\end{array}$ & Remote & $2.04 \pm 0.38$ & $4.5 \pm 5.4$ & $3.0 \pm 2.5$ & $\begin{array}{l}\text { Mar-04- } \\
\text { May-04 }\end{array}$ & $1.46(1.20-2.32)$ & $20.6(0.02-94.8)$ & $52(0.02-274)$ & 15 \\
\hline
\end{tabular}

*: 1:(Wang et al., 2007); 2: (Wang et al., 2006); 3: (Liu et al., 2002); 4: (Fang et al., 2004); 5: (Fang et al., 2001); 6: (Feng et al., 2004a); 7: (Yang et al., 2009); 8: (Xiu et al., 2009); 9: (Fu et al., 2008a); 10: (Fu et al., 2008b); 11: (Wan et al., 2009b); 12: (Wan et al., 2009a); 13: (Kim et al., 2009); 14: (Nguyen et al., 2007); 15: (Chand et al., 2008).

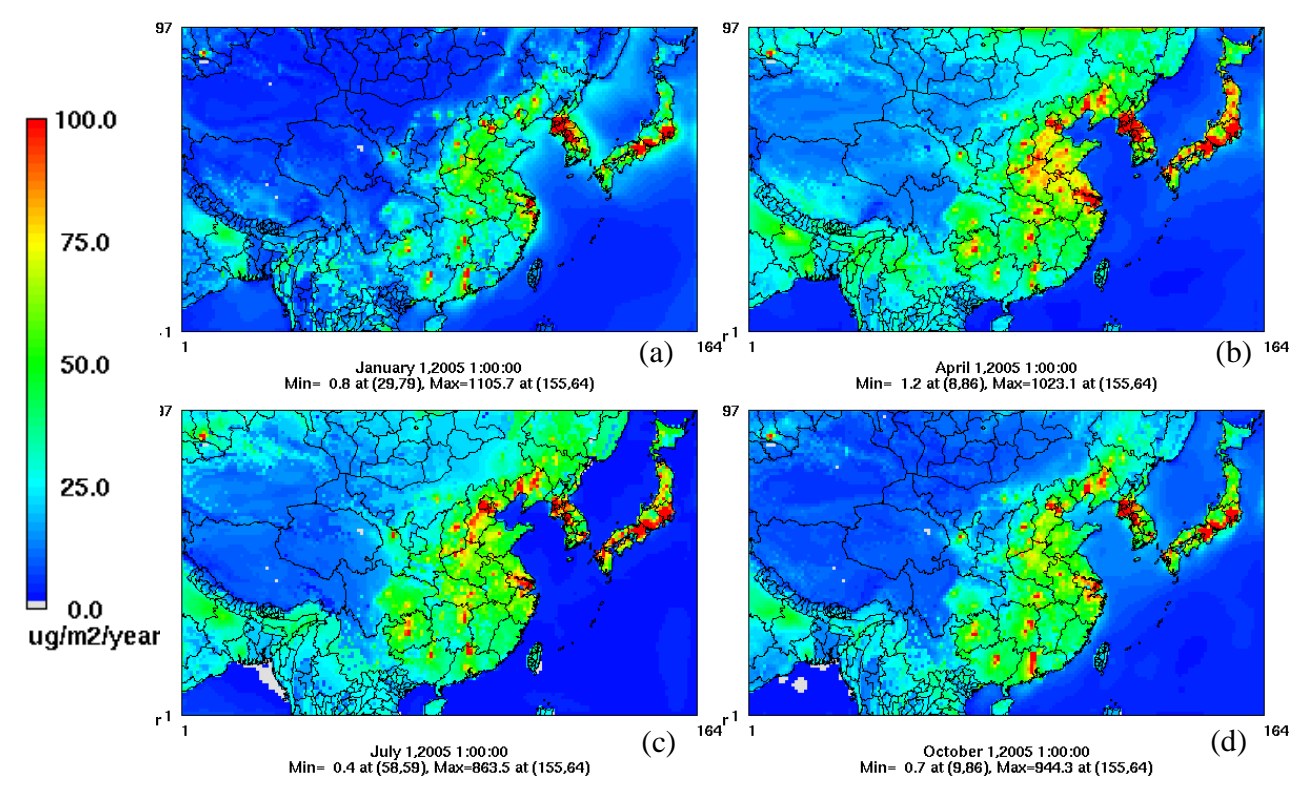

Fig. 4. Spatial distribution of the monthly cumulated dry deposition (normalized to annual deposition, $\mu \mathrm{g} \mathrm{m}^{-2} \mathrm{yr}^{-1}$ ) using the Base case emissions and GEOS-Chem BC/ICs in (a) January, (b) April, (c) July, and (d) October. 


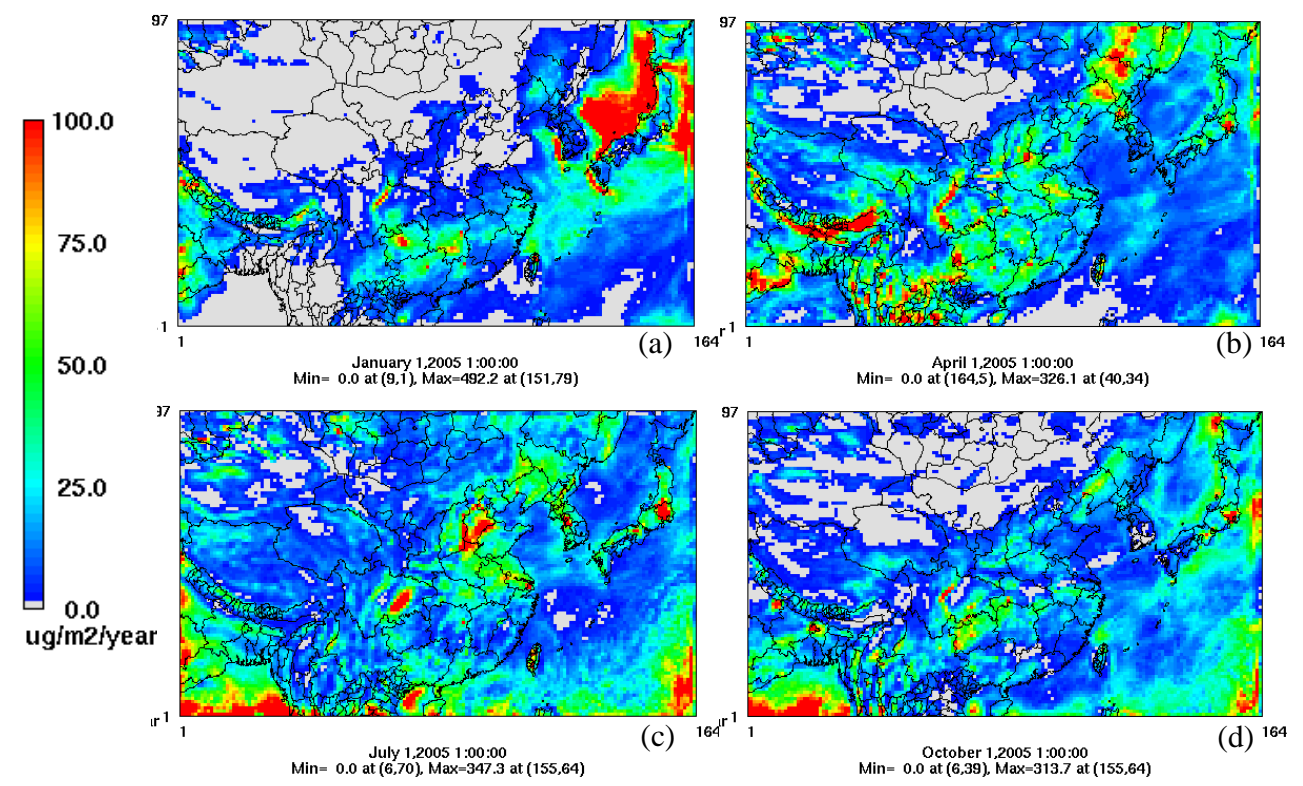

Fig. 5. Spatial distribution of the monthly cumulated wet deposition (normalized to annual deposition, $\mu \mathrm{m}^{-2} \mathrm{yr}^{-1}$ ) using the Base case emissions and GEOS-Chem BC/ICs in (a) January, (b) April, (c) July, and (d) October.

compared to other months, a result caused by a combination of relatively low planetary boundary layer height and chemical oxidation of GEM (more discussion in Sect. 3.3).

The spatial distribution of wet deposition was highly correlated with the locations where precipitation occurred and had very large seasonal variability (Fig. 5). The wet deposition of mercury typically ranged from 5 to $100 \mu \mathrm{g} \mathrm{m}^{-2} \mathrm{yr}^{-1}$ in the study domain. The total wet deposition was comparable but somewhat smaller than the total dry deposition (Table 3). This is consistent with the model results in North America that wet deposition contributes to $30-50 \%$ of total mercury deposition (Lin et al., 2007). Among the four modeling months, July had the greatest wet deposition because of the relatively greater precipitation and more significant chemical oxidation of GEM. The high values of wet deposition at the south border in July and October were caused by the high RGM concentration from the BCs in the south boundary in both months.

The scarcity of observations for dry and wet mercury deposition limited the evaluation of model performance for mercury deposition. In China, wet deposition of $35 \mu \mathrm{g} \mathrm{m}{ }^{-2} \mathrm{yr}^{-1}$ was reported in a rural area (Wujiang River Basin) in Guizhou in 2006 (Guo et al., 2008). Also, wet deposition of $150 \mathrm{\mu g} \mathrm{m}^{-2} \mathrm{yr}^{-1}$ and dry deposition of $170 \mu \mathrm{g} \mathrm{m}^{-2} \mathrm{yr}^{-1}$ in the urban area of Changchun from July 1999 to July 2000 were also reported (Feng et al., 2004b). The dry and wet deposition of mercury predicted by the model was of the same order of magnitude with the reported values (15-120 $\mathrm{g} \mathrm{m}^{-2} \mathrm{yr}^{-1}$ of wet deposition and $30-130 \mu \mathrm{g} \mathrm{m}^{-2} \mathrm{yr}^{-1}$ of dry deposition in Wujiang River Basin; and 35-260 $\mathrm{g} \mathrm{m}^{-2} \mathrm{yr}^{-1}$ of wet deposition and 75-
$480 \mu \mathrm{g} \mathrm{m}^{-2} \mathrm{yr}^{-1}$ of dry deposition in Changchun, Jilin from the model results).

\subsection{Regional mercury budgets and outflow caused by the East Asian emissions}

The regional mercury mass budgets of emission $(E)$, deposition $(D)$, and the total mercury mass at the beginning and the end of each modeling month (IM and $F M$ ) as defined in Eq. (1) were calculated for GEM, RGM and PHg from CMAQ-Hg model data. These values, as well as their transport budgets estimated according to Eq. (2), are summarized in Table 3. It should be noted that the transport budgets calculated by Eq. (2) could not separate the deposition caused by RGM/PHg emissions from the deposition caused by GEM oxidation. Instead, they indicated the transport balances after considering various atmospheric processes such as chemistry and deposition.

From Table 3, it is clear that dry deposition was the primary removal mechanism for RGM and that wet deposition was the main removal mechanism for PHg, although the dry and wet deposition fluxes were of the same order of magnitude on the four-month basis. GEM was primarily removed through dry deposition due to its low solubility in the aqueous phase and vegetation uptakes (Lin and Pehkonen, 1999; Lin et al., 2006a). The dry deposition of GEM had very large seasonal variability, with the greatest removal in July due to the decreased deposition resistance in the summer month (Lin et al., 2006a; Zhang et al., 2009). Assuming that annual deposition is equal to three times the four-month sum, we estimated that the total annual mercury deposition was 
Table 3. Mercury mass budgets in the study domain $\left(\mathrm{Mg}\right.$ month $\left.^{-1}\right)$.

\begin{tabular}{|c|c|c|c|c|c|c|c|c|c|c|c|c|}
\hline \multirow{2}{*}{$\begin{array}{c}\text { Model Month } \\
\text { Species } \\
\end{array}$} & \multicolumn{3}{|c|}{ January } & \multicolumn{3}{|c|}{ April } & \multicolumn{3}{|c|}{ July } & \multicolumn{3}{|c|}{ October } \\
\hline & GEM & RGM & PHg & GEM & RGM & PHg & GEM & RGM & PHg & GEM & RGM & PHg \\
\hline Initial Hg Mass & 366.2 & 14.4 & 22.3 & 370.6 & 17.4 & 22.7 & 404.0 & 12.2 & 11.7 & 399.7 & 11.6 & 12.3 \\
\hline Final Hg Mass & 369.3 & 14.2 & 21.3 & 400.3 & 15.3 & 18.9 & 439.6 & 11.7 & 10.6 & 375.8 & 14.0 & 18.3 \\
\hline Emissions & 67.7 & 22.8 & 7.5 & 114.7 & 22.0 & 7.3 & 181.2 & 22.8 & 7.5 & 112.6 & 22.8 & 7.5 \\
\hline Wet deposition & 0.003 & 7.6 & 18.7 & 0.005 & 10.8 & 25.2 & 0.016 & 16.9 & 23.2 & 0.008 & 13.1 & 16.6 \\
\hline Dry deposition & 2.5 & 22.2 & 3.1 & 9.3 & 26.4 & 6.4 & 17.6 & 18.0 & 2.4 & 9.0 & 22.4 & 2.3 \\
\hline Transport Budget & 62.1 & -6.8 & -13.3 & 75.7 & -13.1 & -20.5 & 128.0 & -11.6 & -17.0 & 127.5 & -15.1 & -17.4 \\
\hline $\begin{array}{l}\text { Net Transport Budget } \\
\text { (GEM+RGM+PHg) }\end{array}$ & & 42.0 & & & 42.1 & & & 99.3 & & & 95.0 & \\
\hline
\end{tabular}

$821 \mathrm{Mg}$ in the East Asian domain for the modeling year, with $396 \mathrm{Mg}$ contributed by wet deposition and $425 \mathrm{Mg}$ by dry deposition.

For the four modeling months, the transport budget (Eq. 2) of GEM was consistently positive $\left(62-128 \mathrm{Mg}\right.$ month $\left.^{-1}\right)$, while the transport budgets of RGM $\left(-15--7 \mathrm{Mg}\right.$ month $\left.^{-1}\right)$ and $\mathrm{PHg}\left(-21--13 \mathrm{Mg} \mathrm{month}^{-1}\right)$ were consistently negative (Table 3). These indicated that there was a net transport of GEM mass out of the East Asian region and a net removal of RGM/PHg from air in the region, consistent with earlier findings by a global model (Strode et al., 2008). The GEM mass leaving the domain showed strong seasonal variability and was the greatest in July $\left(128 \mathrm{Mg} \mathrm{month}^{-1}\right)$ because of the increased GEM emissions from natural sources. This was about twice as much as the value in January $\left(62 \mathrm{Mg}\right.$ month $\left.^{-1}\right)$. The removal of RGM and PHg showed weaker seasonal variability (20-34 Mg month ${ }^{-1}$ combined) compared to that of GEM export. The variability was mainly due to the wet deposition. The relatively smaller variability in dry deposition was caused by the offset of boundary layer mixing with chemical oxidation of GEM. For example, although January had weaker GEM oxidation that led to lower values of dry deposition, the shallower mixing height in the month caused greater RGM/PHg deposition due to less emission dilution. Summing up the transport budgets of GEM, RGM and PHg, there was an overall "export" of mercury from the East Asian region. The greatest transport quantity occurred in July $\left(99 \mathrm{Mg}\right.$ month $^{-1}$ ), more than twice as much as the value in January $\left(42 \mathrm{Mg}\right.$ month $\left.^{-1}\right)$. On an annual basis, it was estimated that $835 \mathrm{Mg}$ of mercury were exported from the study domain, primarily in the form of GEM.

In the absence of mercury emission input, the mercury mass entering the model domain by boundary transport should be readily removed through chemical oxidation of GEM followed by dry and wet deposition. The estimated transport budgets with zero mercury emission in January, April, July and October of the modeling year were 34, 48, 50 , and $45 \mathrm{Mg}$, respectively (all net removal). If mercury emissions were included in model simulations, the transport budgets changed from net removal to net export. This sug- gested that the mercury emissions in the domain not only offset the removal of mercury mass in air coming into the domain, but also resulted in additional mercury mass in air leaving the domain.

The mercury outflow caused by the mercury emissions in the domain under the three emission scenarios (Table 1) was estimated using Eq. (3). The results are shown in Fig. 6, which also exhibits strong seasonal variability. Because the anthropogenic EI in the Base case has been thought to be underestimated, the estimated outflow in this case should be considered a lower limit. The "Inferred" case used the scaled-up EI (Pan et al., 2007), therefore the estimated outflow could be considered an upper limit. Assuming that the annual outflow is three times the four-month sum, the estimated East Asian mercury outflow caused by emissions was in the range of $1369-1671 \mathrm{Mg} \mathrm{yr}^{-1}$ in the modeling year. For the scenario where no anthropogenic emission was considered ("Natural Only" case), the mercury outflow caused by emissions from natural sources amounted to $805 \mathrm{Mg} \mathrm{yr}^{-1}$.

The difference in the estimated annual emission outflow between the "Base/Inferred" case and the "Natural Only" case was the outflow caused by anthropogenic mercury emission in the region. For the Base case, the estimated anthropogenic emission outflow was $564 \mathrm{Mg} \mathrm{yr}^{-1}$; while the outflow for the Inferred case was $866 \mathrm{Mg} \mathrm{yr}^{-1}$. These corresponded to $68 \%$ (Base) and 62\% (Inferred) of the anthropogenic emissions in the domain. The emission outflow percentage in the Inferred case was smaller because a greater percentage of emitted RGM/PHG deposited near the emission sources compared to that in the Base case. Overall, we estimated that about $75 \%$ of mercury emissions in the East Asian region resulted in out-of-boundary transport $(76 \%$ in the Base case; $74 \%$ in the Inferred case; $83 \%$ in the Natural Only case). 


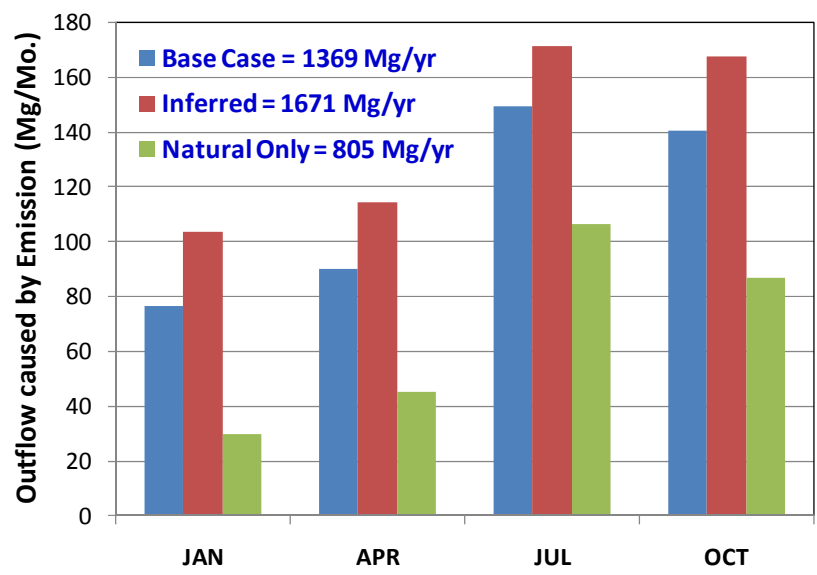

Fig. 6. Estimated mercury outflows of total mercury caused by the emissions in East Asia under various emission scenarios.

\subsection{Implications on intercontinental and trans-boundary transport}

Trans-Pacific and trans-boundary mercury transport events have been reported in a number of recent studies (Jaffe et al., 2005; Jaffe and Strode, 2008; Strode et al., 2008; Kim et al., 2005, 2009). Our earlier modeling assessment of the transPacific transport of mercury showed that direct transport of Asian mercury plumes to North America is insignificant because the plumes have been much diluted during the process of long-range transport (Lin et al., 2006a). However, the mercury input to the atmosphere by the emission outflow from the region can be significant. Based on the assessment in this study, the annual mercury emission outflow from the region was in the range of $1369-1671 \mathrm{Mg} \mathrm{yr}^{-1}$, mainly in the form of GEM. Considering the current global mercury burden of $5000-6000 \mathrm{Mg}$ in the atmosphere and the lifetime of atmospheric mercury at about one year (Mason and Sheu, 2002; Selin et al., 2007), the emission outflow represented about $20-30 \%$ of the global burden. Because mercury deposition at remote receptor sites is linear to the release of mercury into the atmosphere, the input to the global mercury pool from the East Asian emission outflow would contribute to about 20$30 \%$ of the deposition in areas remote from mercury emission sources. This estimate seemed to be consistent with the results of the global model estimates of $18-26 \%$ (Strode et al., 2008; Seigneur et al., 2004).

Kim et al. (2009) reported that 25 of the 70 elevated total gaseous mercury (TGM) episodes observed at a ground station in Seoul, South Korea from February 2005 to February 2006 were caused by the anthropogenic mercury plumes emitted in the industrial areas of China (34 episodes caused by local events). Based on the findings in Kim et al. (2009) and the model results in this study, we concluded that the trans-boundary mercury transport events should occur episodically. Due to the long atmospheric lifetime of GEM, which typically consitutes more than $95 \%$ of TGM, there would be a concentration gradient if there were persistent winds carrying the emitted mercury to downwind locations. This can be seen in Fig. 3 from the East Asian continent to the Pacific. However, the model-predicted surface TGM fields did not exhibit a gradient from the industrial areas in China (e.g., Liaoning province) to Korea in both the Base (Fig. 3) and the Inferred cases. The observed TGM concentration at the Changbaisan site (at the border of China and the Korean peninsula, $3.7 \mathrm{ng} \mathrm{m}^{-3}$ mean surface concentration) (Wan et al., 2009a, b) was not significantly higher than the observed concentrations in Seoul, South Korea (3.3 $\mathrm{ng} \mathrm{m}^{-3}$ mean surface concentration) (Kim et al., 2009), either. On the other hand, the aircraft observations of mercury emission outflow during ACE-Asia campaign did detect mercury plumes at high altitudes ( $>3 \mathrm{~km}$ above sea level) (Pan et al., 2006). In the events of air subsidence, it would be possible for the ground-level monitors to detect the signals of direct transport of anthropogenic plumes. The impact of such episodic transport events on dry and wet mercury depositions at the receptor sites, which is the primary concern of mercury pollution, requires further modeling assessment.

\section{Conclusions}

In this study, we investigated the regional chemical transport of atmospheric mercury in East Asia and the mercury emission outflow from the region using a comprehensive modeling approach coupled with regional mass balance analyses. Compared to earlier assessments that employed direct flux estimate based on measurements or receptor modeling (e.g., Weiss-Penzias et al., 2007; Kim et al., 2009), the modeling approach in this work considered atmospheric processes (emission, chemistry, dispersion, transport, and deposition, etc.) in the outflow evaluation. This study marks the first regional modeling assessment in a source region that accounts for nearly $50 \%$ of the global anthropogenic mercury emissions.

The predicted monthly average surface concentrations of total mercury resembled the spatial distribution of GEM emissions from natural sources, with concentration hotspots caused by large point sources in China, Korea and Japan. The concentration gradient from the Asian continent to the Pacific suggested significant mercury outflows. In the East Asian region, the dry deposition was mainly contributed by RGM; while the wet deposition was contributed by both RGM and $\mathrm{PHg}$. The total annual deposition was estimated to be $821 \mathrm{Mg}$ for the modeling year (2005), with $396 \mathrm{Mg}$ contributed by wet deposition and $425 \mathrm{Mg}$ by dry deposition. Most of the deposition was caused by anthropogenic emissions $(616 \mathrm{Mg}$ or $75 \%)$.

Regional mercury mass budgets showed strong seasonal variability, with a net removal of RGM (7-15 Mg month ${ }^{-1}$ ) and $\mathrm{PHg}\left(13-21 \mathrm{Mg} \mathrm{month}^{-1}\right)$ in the study domain, and a 
net export of GEM $\left(60-130 \mathrm{Mg}\right.$ month $\left.^{-1}\right)$ from the domain for all four modeling months. The estimated annual emission outflow from the East Asian region was in the range of $1369-1671 \mathrm{Mg} \mathrm{yr}^{-1}$, of which $50-60 \%$ was caused by emissions from natural sources. This represents about $75 \%$ of total mercury emissions (anthropogenic plus natural) in the region. About $65 \%$ of anthropogenic mercury emissions resulted in outflow, mainly into the Pacific.

The outflow caused by mercury emissions from the East Asian region can contribute significantly to the global mercury pool in the atmosphere. Because mercury deposition at remote receptor sites is linear to the release of mercury into the atmosphere, the mercury outflow from the region can contribute considerably to deposition in regions remote from anthropogenic emissions. We estimated that the mercury outflow from East Asia would contribute to $20-30 \%$ of mercury deposition at remote receptors. Major uncertainties of this assessment include mercury chemical mechanisms and mercury speciation of the anthropogenic emission estimates. Further understanding of mercury chemistry and emission processes will greatly reduce the uncertainties.

Acknowledgements. The study is sponsored in parts by the Texas Air Research Center (Project No: 078LUB3068A), Texas Commission on Environmental Quality (Umbrella Contract No. 582-7-83975), USEPA Office of Air Quality Planning \& Standards (RTI Subcontract Number: 6-321-0210288), and the State Key Laboratory of Environmental Geochemistry, Institute of Geochemistry, Chinese Academy of Sciences. The funding support is gratefully acknowledged.

Edited by: K.-H. Kim

\section{References}

Bullock, O. R. and Brehme, K. A.: Atmospheric mercury simulation using the cmaq model: Formulation description and analysis of wet deposition results, Atmos. Environ., 36, 2135-2146, 2002.

Byun, D. W. and Ching, J. K. S.: Science algorithms of the EPA Models-3 Community Multiscale Air Quality (CMAQ) modeling system. Rep EPA-600/R-99/030, Office of Research and Development, US Environmental Protection Agency, Washington, DC, 1999.

Byun, D. and Schere, K. L.: Review of the governing equations, computational algorithms, and other components of the models3 community multiscale air quality (CMAQ) modeling system, Appl. Mech. Rev., 59, 51-77, doi:10.1115/1.2128636, 2006.

Carmichael, G. R., Tang, Y., Kurata, G., Uno, I., Streets, D. G., Thongboonchoo, N., Woo, J. H., Guttikunda, S., White, A., Wang, T., Blake, D. R., Atlas, E., Fried, A., Potter, B., Avery, M. A., Sachse, G. W., Sandholm, S. T., Kondo, Y., Talbot, R. W., Bandy, A., Thorton, D., and Clarke, A. D.: Evaluating regional emission estimates using the trace-p observations, J. Geophys. Res.-Atmos., 108, 8810, doi:10.1029/2002jd003116, 2003.

Chand, D., Jaffe, D., Prestbo, E., Swartzendruber, P. C., Hafner, W., Weiss-Penzias, P., Kato, S., Takami, A., Hatakeyama, S., and
Kajii, Y.: Reactive and particulate mercury in the Asian marine boundary layer, Atmos. Environ., 42, 7988-7996, 2008.

Choi, E. M., Kim, S. H., Holsen, T. M., and Yi, S. M.: Total gaseous concentrations in mercury in Seoul, Korea: Local sources compared to long-range transport from china and Japan, Environ. Pollut., 157, 816-822, doi:10.1016/j.envpol.2008.11.023, 2009.

Fang, F., Wang, Q., Liu, R., Ma, Z., and Hao, Q.: Atmospheric particulate mercury in Changchun city, china, Atmos. Environ., 35, 4265-4272, 2001.

Fang, F. M., Wang, Q. C., and Li, J. F.: Urban environmental mercury in Changchun, a metropolitan city in northeastern China: Source, cycle, and fate, Sci. Total Environ., 330, 159170, doi:10.1016/j.scitotenv.2004.04.006, 2004.

Feng, X. B., Shang, L. H., Wang, S. F., Tang, S. L., and Zheng, W.: Temporal variation of total gaseous mercury in the air of Guiyang, China, J. Geophys. Res.-Atmos., 109, D03303, doi:10.1029/2003JD004159, 2004a.

Feng, X. B., Yan, H. Y., Wang, S. F., Qiu, G. L., Tang, S. L., Shang, L. H., Dai, Q. J., and Hou, Y. M.: Seasonal variation of gaseous mercury exchange rate between air and water surface over Baihua reservoir, Guizhou, China, Atmos. Environ., 38, 4721-4732, 2004 b.

Feng, X. B., Wang, S. F., Qiu, G. A., Hou, Y. M., and Tang, S. L.: Total gaseous mercury emissions from soil in Guiyang, Guizhou, China, J. Geophys. Res.-Atmos., 110, D14306, doi:10.1029/2004JD005643, 2005.

Friedli, H. R., Radke, L. F., Prescott, R., Li, P., Woo, J. H., and Carmichael, G. R.: Mercury in the atmosphere around Japan, Korea, and china as observed during the 2001 ACEAsia field campaign: Measurements, distributions, sources, and implications, J. Geophys. Res.-Atmos., 109, D19S25, doi:10.1029/2003jd004244, 2004.

Fu, X. W., Feng, X. B., Zhu, W. Z., Wang, S. F., and Lu, J. L.: Total gaseous mercury concentrations in ambient air in the eastern slope of Mt. Gongga, south-eastern fringe of the Tibetan plateau, china, Atmos. Environ., 42, 970-979, 2008a.

Fu, X. W., Feng, X. B., Zhu, W. Z., Zheng, W., Wang, S. F., and Lu, J. Y.: Total particulate and reactive gaseous mercury in ambient air on the eastern slope of the Mt. Gongga area, China, Appl. Geochem., 23, 408-418, 2008b.

Grell, G. A., Dudhia, J., and Stauffer, D. R.: A description of the fifth-generation Penn State/NCAR Mesoscale Model (MM5), NCAR Tech Note TN-398 + STR, 122 pp., 1994.

Guo, Y., Feng, X., Li, Z., He, T., Yan, H., Meng, B., Zhang, J., and Qiu, G.: Distribution and wet deposition fluxes of total and methyl mercury in Wujiang river basin, Guizhou, China, Atmos. Environ., 42, 7096-7103, 2008.

Holmes, C. D., Jacob, D. J., Mason, R. P., and Jaffe, D. A.: Sources and deposition of reactive gaseous mercury in the marine atmosphere, Atmos. Environ., 43, 2278-2285, 2009.

Jaffe, D., Prestbo, E., Swartzendruber, P., Weiss-Penzias, P., Kato, S., Takami, A., Hatakeyama, S., and Kajii, Y.: Export of atmospheric mercury from Asia, Atmos. Environ., 39, 3029-3038, doi:10.1016/j.atmosenv.2005.01.030, 2005.

Jaffe, D. and Strode, S.: Sources, fate and transport of atmospheric mercury from Asia, Environ. Chem., 5, 121-126, doi:10.1071/en08010, 2008.

Kim, K. H., Ebinghaus, R., Schroeder, W. H., Blanchard, P., Kock, H. H., Steffen, A., Froude, F. A., Kim, M. Y., Hong, S. M., and 
Kim, J. H.: Atmospheric mercury concentrations from several observatory sites in the northern hemisphere, J. Atmos. Chem., 50, 1-24, doi:10.1007/s10874-005-9222-0, 2005.

Kim, S. H., Han, Y. J., Holsen, T. M., and Yi, S. M.: Characteristics of atmospheric speciated mercury concentrations (TGM, $\mathrm{Hg}$ (II) and $\mathrm{Hg}(\mathrm{p})$ ) in Seoul, Korea, Atmos. Environ., 43, 3267-3274, doi:10.1016/j.atmosenv.2009.02.038, 2009.

Lamborg, C. H., Fitzgerald, W. F., Vandal, G. M., and Rolfhus, K. R.: Atmospheric mercury in northern Wisconsin - sources and species, Water Air Soil Pollut., 80, 189-198, 1995.

Lin, C. J. and Pehkonen, S. O.: The chemistry of atmospheric mercury: A review, Atmos. Environ., 33, 2067-2079, 1999.

Lin, C.-J., Pongprueksa, P., Streets, D. G., Jang, C., Ho, T., and Chu, H.: Trans-Pacific Chemical Transport of Mercury: Sensitivity Analysis on Potential Asian Emission Contribution to Mercury Deposition in North America Using CMAQ-Hg, The 5th CMAS Conference, Research Triangle Park, NC, 16-18 October, 2006a.

Lin, C. J., Pongprueksa, P., Lindberg, S. E., Pehkonen, S. O., Byun, D., and Jang, C.: Scientific uncertainties in atmospheric mercury models I: Model science evaluation, Atmos. Environ., 40, 29112928, doi:10.1016/j.atmosenv.2006.01.009, 2006b.

Lin, C. J., Pongprueks, P., Rusell Bulock, O., Lindberg, S. E., Pehkonen, S. O., Jang, C., Braverman, T., and Ho, T. C.: Scientific uncertainties in atmospheric mercury models II: Sensitivity analysis in the CONUS domain, Atmos. Environ., 41, 65446560, doi:10.1016/j.atmosenv.2007.04.030, 2007.

Lindberg, S., Bullock, R., Ebinghaus, R., Engstrom, D., Feng, X. B., Fitzgerald, W., Pirrone, N., Prestbo, E., and Seigneur, C.: A synthesis of progress and uncertainties in attributing the sources of mercury in deposition, Ambio, 36, 19-32, 2007.

Lindberg, S. E., Brooks, S., Lin, C. J., Scott, K. J., Landis, M. S., Stevens, R. K., Goodsite, M., and Richter, A.: Dynamic oxidation of gaseous mercury in the arctic troposphere at polar sunrise, Environ. Sci. Technol., 36, 1245-1256, doi:10.1021/es0111941, 2002.

Liu, S. L., Nadim, F., Perkins, C., Carley, R. J., Hoag, G. E., Lin, Y. H., and Chen, L. T.: Atmospheric mercury monitoring survey in Beijing, China, Chemosphere, 48, 97-107, 2002.

Mason, R. P., Morel, F. M. M., and Hemond, H. F.: The role of microorganisms in elemental mercury formation in natural-waters, Water Air Soil Pollut., 80, 775-787, 1995.

Mason, R. P. and Sheu, G. R.: Role of the ocean in the global mercury cycle, Global Biogeochem. Cy., 16, 1093, doi:10.1029/2001gb001440, 2002.

Mason, R. P., Kim, E. H., Cornwell, J., and Heyes, D.: An examination of the factors influencing the flux of mercury, methylmercury and other constituents from estuarine sediment, Marine Chem., 102, 96-110, doi:10.1016/j.marchem.2005.09.021, 2006.

Miller, C. L., Mason, R. P., Gilmour, C. C., and Heyes, A.: Influence of dissolved organic matter on the complexation of mercury under sulfidic conditions, Environ. Toxic. Chem., 26, 624-633, 2007.

Moussiopoulos, N., Helmis, C. G., Flocas, H. A., Louka, P., Assimakopoulos, V. D., Naneris, C., and Sahm, P.: A modelling method for estimating transboundary air pollution in southeastern Europe, Environ. Model. Softw., 19, 549-558, doi:10.1016/j.envsoft.2003.07.003, 2004.

Nguyen, H. T., Kim, K. H., Kim, M. Y., Hong, S. M., Youn, Y. H.,
Shon, Z. H., and Lee, J. S.: Monitoring of atmospheric mercury at a global atmospheric watch (gaw) site on an-myun island, korea, Water Air Soil Pollut., 185, 149-164, doi:10.1007/s11270007-9438-5, 2007.

Pacyna, E. G., Pacyna, J. M., Steenhuisen, F., and Wilson, S.: Global anthropogenic mercury emission inventory for 2000, Atmos. Environ., 40, 4048-4063, 2006.

Pan, L., Woo, J. H., Carmichael, G. R., Tang, Y. H., Friedli, H. R., and Radke, L. F.: Regional distribution and emissions of mercury in East Asia: A modeling analysis of Asian pacific regional aerosol characterization experiment (ACEAsia) observations, J. Geophys. Res.-Atmos., 111, D07109, doi:10.1029/2005jd006381, 2006.

Pan, L., Chai, T. F., Carmichael, G. R., Tang, Y. H., Streets, D., Woo, J. H., Friedli, H. R., and Radke, L. F.: Top-down estimate of mercury emissions in china using four-dimensional variational data assimilation, Atmos. Environ., 41, 2804-2819, doi:10.1016/j.atmosenv.2006.11.048, 2007.

Pan, L., Carmichael, G. R., Adhikary, B., Tang, Y. H., Streets, D., Woo, J. H., Friedli, H. R., and Radke, L. F.: A regional analysis of the fate and transport of mercury in East Asia and an assessment of major uncertainties, Atmos. Environ., 42, 1144-1159, doi:10.1016/j.atmosenv.2007.10.045, 2008.

Pleim, J. E. and Byun, D. W.: Application of a new land-surface, dry deposition, and PBL model in the models-3 Community MultiScale Air Quality (CMAQ) model system, in: Air Pollution Modeling and Its Application XIV, edited by: Gryning, S. and Schiermeier, F. A., Kluwer Academic Publishers, New York, 297-305, 2004.

Pongprueksa, P., Lin, C. J., Lindberg, S. E., Jang, C., Braverman, T., Bullock, O. R., Ho, T. C., and Chu, H. W.: Scientific uncertainties in atmospheric mercury models III: Boundary and initial conditions, model grid resolution, and hg(ii) reduction mechanism, Atmos. Environ., 42, 1828-1845, doi:10.1016/j.atmosenv.2007.11.020, 2008.

Rolfhus, K. R., Sakamoto, H. E., Cleckner, L. B., Stoor, R. W., Babiarz, C. L., Back, R. C., Manolopoulos, H., and Hurley, J. P.: Distribution and fluxes of total and methylmercury in lake superior, Environ. Sci. Technol., 37, 865-872, 2003.

Schroeder, W. H., Anlauf, K. G., Barrie, L. A., Lu, J. Y., Steffen, A., Schneeberger, D. R., and Berg, T.: Arctic springtime depletion of mercury, Nature, 394, 331-332, 1998.

Schroeder, W. H. and Munthe, J.: Atmospheric mercury - an overview, Atmos. Environ., 32, 809-822, 1998.

Seigneur, C., Vijayaraghavan, K., Lohman, K., Karamchandani, P., and Scott, C.: Global source attribution for mercury deposition in the united states, Environ. Sci. Technol., 38, 555-569, doi:10.1021/es034109t, 2004.

Selin, N. E., Jacob, D. J., Park, R. J., Yantosca, R. M., Strode, S., Jaegle, L., and Jaffe, D.: Chemical cycling and deposition of atmospheric mercury: Global constraints from observations, J. Geophys. Res.-Atmos., 112, D02308, doi:10.1029/2006jd007450, 2007.

Shetty, S. K., Lin, C. J., Streets, D. G., and Jang, C.: Model estimate of mercury emission from natural sources in East Asia, Atmos. Environ., 42, 8674-8685, doi:10.1016/j.atmosenv.2008.08.026, 2008.

Shia, R. L., Seigneur, C., Pai, P., Ko, M., and Sze, N. D.: Global simulation of atmospheric mercury concentrations and deposi- 
tion fluxes, J. Geophys. Res.-Atmos., 104, 23747-23760, 1999.

Stratton, W. J., Lindberg, S. E., and Perry, C. J.: Atmospheric mercury speciation: Laboratory and field evaluation of a mist chamber method for measuring reactive gaseous mercury, Environ. Sci. Technol., 35, 170-177, 2001.

Streets, D. G., Hao, J. M., Wu, Y., Jiang, J. K., Chan, M., Tian, H. Z., and Feng, X. B.: Anthropogenic mercury emissions in china, Atmos. Environ., 39, 7789-7806, 2005.

Streets, D. G., Zhang, Q., and Wu, Y.: Projection of global mercury emission in 2050, Environ. Sci. Technol., 43, 2983-2988, 2009.

Strode, S. A., Jaegle, L., Jaffe, D. A., Swartzendruber, P. C., Selin, N. E., Holmes, C., and Yantosca, R. M.: Trans-pacific transport of mercury, J. Geophys. Res.-Atmos., 113, D15305, doi:10.1029/2007jd009428, 2008.

Wan, Q., Feng, X. B., Lu, J., Zheng, W., Song, X. J., Li, P., Han, S. J., and $\mathrm{Xu}, \mathrm{H} .:$ Atmospheric mercury in Changbai mountain area, northeastern china II: The distribution of reactive gaseous mercury and particulate mercury and mercury deposition fluxes, Environ. Res., 109, 721-727, 2009a.

Wan, Q., Feng, X. B., Lu, J. L., Zheng, W., Song, X. J., Han, S. J., and $\mathrm{Xu}, \mathrm{H}$.: Atmospheric mercury in Changbai mountain area, northeastern China I: The seasonal distribution pattern of total gaseous mercury and its potential sources, Environ. Res., 109, 201-206, 2009b.

Wang, Z. W., Zhang, X. S., Chen, Z. S., and Zhang, Y.: Mercury concentrations in size-fractionated airborne particles at urban and suburban sites in Beijing, China, Atmos. Environ., 40, 2194-2201, 2006.

Wang, Z. W., Chen, Z. S., Duan, N., and Zhang, X. S.: Gaseous elemental mercury concentration in atmosphere at urban and remote sites in china, J. Environ. Sci.-China, 19, 176-180, 2007.
Weiss-Penzias, P., Jaffe, D. A., Swartzendruber, P., Dennison, J. B., Chand, D., Hafner, W., and Prestbo, E.: Observations of Asian air pollution in the free troposphere at mount bachelor observatory during the spring of 2004, J. Geophys. Res.-Atmos., 111, D10304, doi:10.1029/2005jd006522, 2006.

Weiss-Penzias, P., Jaffe, D., Swartzendruber, P., Hafner, W., Chand, D., and Prestbo, E.: Quantifying Asian and biomass burning sources of mercury using the $\mathrm{Hg} / \mathrm{CO}$ ratio in pollution plumes observed at the mount bachelor observatory, Atmos. Environ., 41, 4366-4379, doi:10.1016/j.atmosenv.2007.01.058, 2007.

Wu, Y., Wang, S. X., Streets, D. G., Hao, J. M., Chan, M., and Jiang, J. K.: Trends in anthropogenic mercury emissions in China from 1995 to 2003, Environ. Sci. Technol., 40, 53125318, doi:10.1021/es060406x, 2006.

Xiu, G. L., Cai, J., Zhang, W. Y., Zhang, D. N., Bueler, A., Lee, S. C., Shen, Y., Xu, L. H., Huang, X. J., and Zhang, P.: Speciated mercury in size-fractionated particles in shanghai ambient air, Atmos. Environ., 43, 3145-3154, 2009.

Yang, Y. K., Chen, H., and Wang, D. Y.: Spatial and temporal distribution of gaseous elemental mercury in Chongqing, China, Environ. Monit. Assess., 156, 479-489, 2009.

Zender, C. S. and Mangalarn, H.: Scaling properties of common statistical operators for gridded datasets, International Journal of High Performance Computing Applications, 21, 485-498, doi:10.1177/1094342007083802, 2007.

Zhang, L., Wright, L. P., and Blanchard, P.: A review of current knowledge concerning dry deposition of atmospheric mercury, Atmos. Environ., 43, 5853-5864, 2009. 